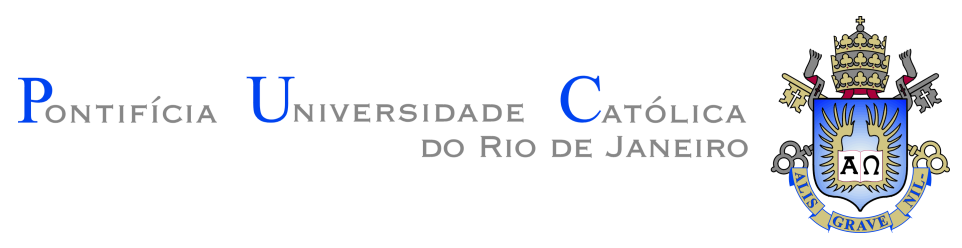

Vítor Araújo de Holanda Jó

Capital Controls in Latin American Economies: Stylized Facts, Optimality and Welfare Analysis

Dissertação de Mestrado

Dissertation presented to the Programa de Pós-graduação em Economia da PUC-Rio in partial fulfillment of the requirements for the degree of Mestre em Economia .

Advisor : Prof. Márcio Gomes Pinto Garcia Co-advisor: Prof. Diogo Abry Guillén 


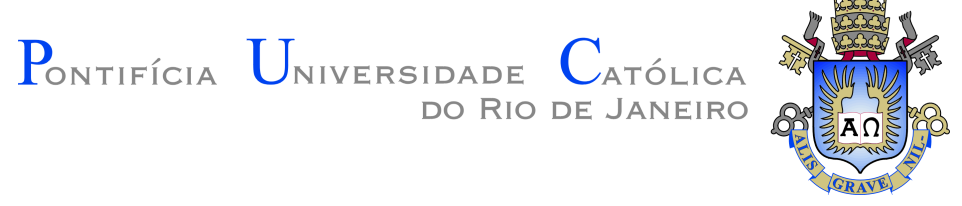

Vítor Araújo de Holanda Jó

\title{
Capital Controls in Latin American Economies: Stylized Facts, Optimality and Welfare Analysis
}

Dissertation presented to the Programa de Pós-graduação em Economia da PUC-Rio in partial fulfillment of the requirements for the degree of Mestre em Economia. Approved by the undersigned Examination Committee.

\author{
Prof. Márcio Gomes Pinto Garcia \\ Advisor \\ Departamento de Economia - PUC-Rio
}

Prof. Diogo Abry Guillén

Co-advisor

Departamento de Economia - PUC-Rio

Prof. Eduardo Zilberman

Departamento de Economia - PUC-Rio

Prof. Maria Cristina Trindade Terra

Department of Economics - ESSEC Business School 
All rights reserved.

\section{Vítor Araújo de Holanda Jó}

B.A., Economics, Universidade Federal de Pernambuco, 2015

Bibliographic data

de Holanda Jó, Vítor Araújo

Capital Controls in Latin American Economies: Stylized Facts, Optimality and Welfare Analysis / Vítor Araújo de Holanda Jó; advisor: Márcio Gomes Pinto Garcia; co-advisor: Diogo Abry Guillén. - Rio de janeiro: PUC-Rio , Departamento de Economia, 2019.

v., 49 f: il. color. ; $30 \mathrm{~cm}$

Dissertação (mestrado) - Pontifícia Universidade Católica do Rio de Janeiro, Departamento de Economia.

Inclui bibliografia

1. Economia - Teses. 2. Economia - Teses. 3. Controles de Capital;. 4. Dívida;. 5. Taxa de juros;. 6. Otimalidade;. 7. Bem-Estar;.

I. Garcia, Márcio Gomes Pinto. II. Guillén, Diogo Abry. III. Pontifícia Universidade Católica do Rio de Janeiro. Departamento de Economia. IV. Título. 


\section{Acknowledgments}

First of all, I thank my parents, Domingos Sávio and Tereza Cristina: you have always been my greatest inspiration. Thank you also to Júlia: your love sustained me in moments that I hesitated.

I thank my professors, Márcio Garcia and Diogo Guillén, real masters in all aspects: I will always feel in debt to you. Eduardo Zilberman and Maria Cristina Terra: thank you very much for the attention and the pertinent comments on this work. I also want to thank Marcelo de Paiva Abreu for the exciting conversations and support during this phase of my life.

Over these two years, I cannot fail to thank my classmates, especially Pedro Kenzo Ohi and Yuri Pinto: you have made the days - and the nights - easier. Finally, I thank God, who allowed me to know more about myself and Him.

This study was financed in part by the Coordenação de Aperfeiçoamento Pessoal de Nível Superior - Brasil (CAPES) - Código de Financiamento 001. 


\section{Abstract}

de Holanda Jó, Vítor Araújo; Garcia, Márcio Gomes Pinto (Advisor); Guillén, Diogo Abry (Co-Advisor). Capital Controls in Latin American Economies: Stylized Facts, Optimality and Welfare Analysis. Rio de Janeiro, 2019. 49p. Dissertação de mestrado - Departamento de Economia, Pontifícia Universidade Católica do Rio de Janeiro.

The present work investigates the relationship between capital controls and external accounts in Latin American economies and addresses the idea of capital control's optimality in a small open economy. The work presents capital controls as countercyclical, where they are intended to mitigate adverse shocks in the current account. Also, using data for the Brazilian economy, the results suggest that capital controls may mitigate the volatility of the economy and allow welfare gains in the steady state. At the same time, the work shows that, at excessive taxation, an ad-hoc capital control loses its capacity to generate welfare gains, which in turn alludes certain parsimony in their introduction.

\section{Keywords}

Captital Controls; Debt; Interest rates; Optimality; Welfare; 


\section{Resumo}

de Holanda Jó, Vítor Araújo; Garcia, Márcio Gomes Pinto; Guillén, Diogo Abry. Controles de Capital em Economias da América Latina: Fatos Estilizados, Otimalidade e Análise de BemEstar. Rio de Janeiro, 2019. 49p. Dissertação de Mestrado Departamento de Economia, Pontifícia Universidade Católica do Rio de Janeiro.

O presente trabalho investiga a relação entre controles de capital e contas externas nas economias da América Latina e aborda a ideia de otimalidade dos controles de capital em uma pequena economia aberta. O trabalho apresenta controles de capital como contracíclicos, em que esses são usados para mitigar choques adversos na conta corrente. Usando dados para a economia brasileira, os resultados também sugerem que controles de capital podem mitigar a volatilidade da economia e permitir ganhos de bem-estar no estado estacionário. Ao mesmo tempo, o trabalho mostra que, com impostos (controles) excessivos, o controle de capital pode perder sua capacidade de gerar ganhos de bem-estar, o que, por sua vez, alude a uma certa parcimônia na introdução dos mesmos.

\section{Palavras-chave}

Controles de Capital; Dívida; Taxa de juros; Otimalidade; BemEstar; 


\section{Table of contents}

1 Introduction $\quad 10$

2 Empirical Setting $\quad 14$

2.1 Panel-VAR 14

2.2 Capital Control Law of Motion 19

2.2.1 Estimating Euler Equation 19

3 General Model $\quad 24$

3.1 Discussion 24

$\begin{array}{ll}3.2 \text { Model } & 26\end{array}$

4 Welfare $\quad 29$

$\begin{array}{lll}4.1 & \text { Welfare Analysis } & 29\end{array}$

4.2 Robustness Results 35

5 Conclusions $\quad 38$

$\begin{array}{lll}\text { A Overborrowing } & 43\end{array}$

$\begin{array}{lll}\text { B Panel-VAR } & 44\end{array}$

$\begin{array}{lll}C & \text { Euler Equation } & 48\end{array}$

D Bayesian Estimation $\quad 49$ 


\section{List of figures}

Figure 2.1 Orthogonalized IRF - 95\% IC; Impulse- Response. Left: Impulse-Controls on Inflows; Response- Net External Position.

Right: Impulse-Current Account; Response- Controls on Inflows. 18

Figure 2.2 Non-Parametric Regression: Capital Controls x Current Account

Figure 3.1 External Debt as share of GNI to Emerging Markets and Emerging Markets from Latin America (Source: OECD).

Figure 4.1 Black: No capital control; Green: Ad-hoc capital control;

Blue: $A d-h o c$ with $\bar{t}=6 \%$. Negative Domestic Shock.

Figure 4.2 Black: No capital control; Green: Ad-hoc capital control. 36

Figure 4.3 Black: Ad-hoc capital control changing $\psi$ between 0.0001 and 0.01; Green: Previous Ad-hoc capital control.

Figure B.1 Orthogonalized IRF - 95\% IC; Impulse: Response. The first quadrant is controlling only by World Growth, the second World Growth and U.S. Treasury and so on.

Figure D.1 Multivariate Convergence Diagnostic. 


\section{List of tables}

Table 2.1 Current Account, CA, (lags) and Index on Inflows (fixed);

Net External Position, NFA, (leads) and Index on Inflows (fixed). 15

Table 2.2 Estimating Euler Equation - GMM. 21

Table 2.3 OLS: Residuals - Accounts 21

Table 2.4 Nonlinear Regression Model. 23

$\begin{array}{llr}\text { Table } 4.1 & \text { Parameters. } & 29\end{array}$

Table 4.2 Correlations $\quad 30$

Table 4.3 Statistical Moments. 31

Table 4.4 Welfare changes in the steady relative to the economy under capital control. 34

$\begin{array}{lll}\text { Table B.1 Model 1. } & 45\end{array}$

Table B.2 Model $2 . \quad 47$

Table C.1 Estimation: Linear Interpolation 48

Table C.2 Estimation: Quadratic Interpolation 48

Table D.1 Estimated parameters. first, $\zeta$; second, $\phi \quad 49$ 


\section{Introduction}

Since the 1990s, emerging market economies began to feel increasing capital inflows from developed economies. Such fact has occurred almost unanimously in all Latin American countries, being potentialized after the Global Financial Crisis (Arora et al. (2013)). The motives that explain such movements can be attributed to cyclical reasons, such as low investment returns in the advanced economies allied to their delicate fiscal situations, as pointed out by Hannan (2018). ${ }^{1}$

Although the capital inflows bring more capacity for financing productive investments and accumulation of reserves, it is also often associated with an appreciation of the real exchange rate and a deterioration of the current account. Such effects eventually worsen when these episodes are related to cyclical reasons, which can amplify distortions in economies with frictions. In the face of that, local authorities try to mitigate inflows by adopting capital controls on them. Examples of this are Argentina (2001), Chile (1990), Colombia (2002), Mexico (1990), Peru (2009) and Brazil several times, especially after the Global Financial Crisis (Magud et al. (2018) ).

The present work investigates stylized facts of capital controls on inflows and addresses the idea of capital control's optimality in a small open economy. It shows capital controls as countercyclical, where they are designed to mitigate adverse shocks in the current account. Moreover, we also present that the controls implemented between 1995 and 2015 could, indeed, improve the situation of net external position, through portfolio equities, in the LatAm economies. Besides that, the work proposes a law o movement of capital control for the Brazilian economy, based on econometric methods and the literature, and tries to understand in which sense such controls could act as stabilizers and generate welfare improvements. For this purpose, we use an RBC model where the domestic interest rates are increasing in the degree of indebtedness and where the capital controls are endogenous, trying to offset the net external position of the economy.

Initially, the work starts investigating the relationship between capital

\footnotetext{
${ }^{1}$ Two crucial variables that directly relate to this capital inflow are the US interest rates and the economic growth of emerging economies.
} 
controls and the external accounts in LatAm economies. Such enterprise is made crossing the following databases: Fernandez et al. (2016) and Lane et al. (2015). The approach is made through a Panel-VAR, in order to considerate the effects of capital controls in many countries (eighteen in total), at the same time. The goal here is to provide general stylized facts in order to understand the motives and consequences of the impositions of capital controls on inflows by policymakers. The main results here are consistent with the idea the local authorities use capital controls on inflows in order to compensate disturbances in the current account - due to the appreciation in the exchange rate - especially imposing controls on portfolio equities accounts. These results are robust for different models and many specifications.

Still, through econometric methods, the work proposes a specific law of motion for the capital control (Ad-hoc's) in the Brazilian economy between 1995 and 2015, using the data presented in the Panel-VAR and through the approach taken by the literature. The goal extracting this law of movement is to build an RBC model where we can simulate two economies: one economy free of capital controls and one other under capital controls. Specifically, we will submit the capital control's law to different specifications and parameters, in order to answer the following questions: can capital controls work as a good stabilizer in the face of negative shocks? Can capital controls generate welfare improvements in the steady state?

So, we present an adapted Real Business Cycle model, simulating a small open economy (SOE). The adaptations incorporate an externality, coming from the increasing interest rate in its degree of indebtedness ("debt-elastic") - a fact that is not internalized by the agents - and a tax, capital control, on the net foreign debt's. ${ }^{2}$ The first adaptation is intended to model the "debt-elastic" environment, which brings the idea of a risk premium. On the other hand, capital control is intended to make the economy less volatile and less subject to an overborrowing. The external effect here makes the debt more expensive as the economy's risk premium increases. That is a usual scenario where the economy is subjected to a negative shock on the output. In their turn, the purpose of capital control is exactly to operate cooling such dynamics.

Using the RBC model, the simulations show that the economy under capital control tends to be more stable. Furthermore, the economy under capital controls may experience an increase in its level of welfare in the steady state for a range of specific values in the capital control's law. Nonetheless, we also show that under Ad-hoc's law, the economy has its potential welfare gains jeopardized when it takes an excessive tax. Such a phenomenon is a

${ }^{2}$ From now on, we will refer to it only as debt. 
crucial result in the work: heuristic impositions of capital controls, even though stabilizing, may harm the welfare of the economy. This last exercise explores the loss of the ability of an $a d-h o c$ capital control to generate welfare gains when it is put heuristically under excessive taxation.

Crossing up different databases, the work extracts a systematic response between capital controls and external accounts for Latin American countries. The empirical results show the capital controls as countercyclical, insofar as they seek to bring stability to the economy after shocks in the current account. Such result is pretty related to those one exposed in Pasricha (2017), where the capital controls would be a reaction to the currency domestic appreciations, and in Zeev (2017), which brings capital controls as a domestic absorber of global shocks in emerging markets. This is also in line with more theoretical literature that relates the impositions of capital controls as stabilizing responses in economies with frictions: Lorenzoni (2008), Jeanne and Korinek (2010) and Benigno and Fornaro (2014) - in particular, Jeanne and Korinek (2010) see capital controls as regular and effective instruments in the implementation of economic policy for these economies.

The work also contributes to the literature that relates capital control and welfare in an general equilibrium model. The first step for this goal is to estimate a capital control law of movement using data from Lane et al. (2015). The underlying idea here is to initiate an investigation behind the variables that most prominently driven the capital control's impositions and, thus, trace considerations about its optimality and its consequences for the economy. The contribution, in this sense, lies more in the idea of this attempt than in its immediate results: in general, the structure of capital controls are simply assumed.

The way that we approach the welfare consequences here is simulating an RBC model under capital control and varying its parameters. So, following Kitano (2011), who show that capital controls may be desirable and generate welfare improvements, we make some simulations in order to explore this feature. Other works already have tried to explore the optimality of capital controls, such as Farhi and Werning (2012) and Schmitt-Grohé and Uribe (2016). Those frameworks explore a nominal rigidity, and approach the literature of optimal taxation. Our framework, however, specifies the RBC environment, under "debt-elastic" relationship, which, in turn, creates a scenario for the imposition of taxes (capital controls) to generate welfare improvements, but not taking into consideration the literature of optimal taxation.

The work is divided into three more chapters. The first is the empirical part, which seeks to investigate the relationship between capital controls and 
external accounts of LatAm countries. Then, we have the adapted RBC model, also discussing the use of such a framework for the goals of the research. Finally, we have the welfare section, where we draw comparisons between the economy under capital controls and without capital controls. The work also has a section for Conclusion, Bibliography, and a final Appendix, which will give more details of certain approaches brought throughout the text. 


\section{2}

\section{Empirical Setting}

The effect of capital controls on inflows among countries still is not so clear in the literature. The goal of this chapter is to provide stylized facts that can contribute to this debate. This chapter begins analyzing how capital controls on inflows are related to the external accounts of Latin American countries. In the second section, the chapter focus on a specific country (Brazil), obtaining a specific capital control law of motion in order to provide the tools for future welfare analysis.

Having said that, we start analyzing how capital controls on inflows are related to shocks in the current accounts of emerging countries, specifically, Latin American: exporting countries, with a relative surge of inflows, and that have certain similarities in social-economic indicators and institutions. The underlying assumption here is to diminish the loss of information by aggregating the data and that is why we focus on LatAm countries.

The analysis was constructed with the following databases: Fernandez et al. and Lane et al. ${ }^{1}$ Fernandez et al. construct a capital control index discriminating between inflows and outflows, with over one hundred countries between 1995 and 2015. In turn, Lane et al. construct estimates of accounts for more than 200 countries between 1970 and 2014 .

\section{1}

\section{Panel-VAR}

The panel's Vector Autoregression (VAR) methodology combines the traditional VAR approach with the panel data, which allows controlling the unobserved heterogeneity in the data and their respective dynamics over time.

The model proposed here will take the following first-order VAR:

$$
z_{i, t}=\Gamma_{0}+\Gamma_{1} z_{i, t-1}+\Psi x_{t}+f_{i}+\epsilon_{t}
$$

Where the vector $z_{i, t}$ represents the endogenous variables and $x_{t}$ the exogenous controls. The variable $f_{i}$ is the individual characteristic of each country. The

\footnotetext{
${ }^{1}$ Fernandez et al.: Capital Controls Measures: A New Dataset, 2016; Lane et al.: International Financial Integration in the Aftermath of the Global Financial Crisis, 2015.
} 
first lag of the variables was the best fit selection criterion through the MBIC, MAIC and MQIC statistics.

We use the Arellano-Bover estimator to overcome the violation of strict exogeneity in dynamic panels with lagged levels of the dependent variable (Arellano and Bover (1995)). This is the procedure used by Love and Zicchino (2006) and in many papers presented in the survey by Canova and Ciccarelli (2013). In this later, they explore a possible inconsistency by Arellano-Bover estimator when $T$ is substantially large. This does not seem the case here, and we still follow the path presented in Love and Zicchino (2006) and Abrigo and Love (2016).

Therefore, we specify a four-variable model for the countries of Latin America: capital Controls on Inflows (KAI), Current Account (CAB), Net External Position (NFA) and GDP growth. The first variable was taken from the updated version (2015) of the index proposed by Fernandez et al. The other three were taken from the Lane et al. database, also in its updated version (2015). The external accounts series had their first differences taken since the cointegration was not possible. The model also has the following exogenous variables: World Growth Rate, U.S. 2-year Treasury, the Global Commodity Price $(2005=100)$ and the VIX (close). The first variables were taken from FRED-St. Louis and the last one from Bloomberg. Data are annual between 1995 and 2015.

The choice of the respective controls was made with the purpose of capturing exogenous effects that operate in the external accounts of the Latin American countries. For example, the world's growth reflects the demand for the products in LatAm as well as the credit conditions to them. American interest rates, in turn, reflects the state of the US economy, as well as its prognosis in the near future, since the US has a high share in the trade dynamics of LatAm and interferes in their capital flows. In addition, the VIX index conveys future conditions for the global economy. Finally, commodity prices directly affect the current results of these economies.

Table 2.1: Current Account, CA, (lags) and Index on Inflows (fixed); Net External Position, NFA, (leads) and Index on Inflows (fixed).

\begin{tabular}{llll|llll}
\hline \hline Current Account & & & & Net External Position & & & \\
LAGS & Mean & Median & Sd & LEADS & Mean & Median & Sd \\
\hline 0 & $-9.2 \%$ & $-9.1 \%$ & 0.21 & 0 & $-16 \%$ & $-19 \%$ & 0.28 \\
1 & $-17 \%$ & $-14 \%$ & 0.16 & 1 & $-14 \%$ & $-13.5 \%$ & 0.16 \\
2 & $-17 \%$ & $-9 \%$ & 0.14 & 2 & $-19 \%$ & $-21 \%$ & 0.13 \\
3 & $-8 \%$ & $-11 \%$ & 0.15 & 3 & $-14 \%$ & $-13 \%$ & 0.23 \\
\hline \hline
\end{tabular}

Table 2.1 aims to present descriptive statistics of the capital controls on inflows and the external accounts of LatAm. It is constructed as follows: the 
left part is made by taking the average of correlations between the lags of the current account and the capital controls on inflows; the part on the right side follows the same idea, but using leads from the NFA proposed by Lane et al. ${ }^{2}$

According to Magud et al. (2018), we can highlight the unwanted appreciation of the currency and the deterioration of the current account as precursors of the imposition of capital controls. Parischa (2017) also relates that capital controls in many emerging markets react to currency appreciation pressures. Such motive is particular and crucial to Latin American economies: the massive inflow of capital puts appreciation pressure on the local currency, jeopardizing net exports. In this sense, we take in our specification shocks in the current account as the most exogenous variable in our model. It is believed that such a hypothesis is reasonable since it relates findings exposed in Magud et al. (2018). ${ }^{3}$ At the same time, the impositions of capital controls are not usually immediate in regard to the exchange rate disturbances and their pressures on the current account (Chamon and Garcia (2016)). On the other hand, capital controls, when imposed, affect components of the financial account, which would affect the current account, but not immediately. Basically, that is the chain of events that underlie the hypothesis of identification (Cholesky Decomposition).

For the dynamic analysis, we estimate the model provided by equation (3-1) and reproduce here the impulse response functions for each of the four specifications - the statistics are in the Appendix. Figure 2.1 illustrates the orthogonalized IRFs (Cholesky Decomposition). The calculation of IRF's standard errors is made through intervals with 1000 Monte Carlo simulations, following Love and Zicchino (2006). The figure suggests that shocks in the current account operate in the opposite direction to the capital controls on inflows. This relationship is robust for the coefficients estimated with all four controls in the model. From the top to the bottom: first, only World Growth; then, World Growth and U.S. 2-year Treasury; then, World Growth, U.S. 2year Treasury and VIX; then World Growth, U.S. 2-year Treasury, VIX and Global Commodity Price. ${ }^{4}$ Besides that, we can see that the impositions of capital controls create a positive dynamic on the NFA account. This is related to the fact that the impositions of controls operate in a positive way for the accounts of portfolio equities and debts, especially in this last one (Magud et al. (2018)). In the Appendix, you can also check a second model, where

\footnotetext{
${ }^{2}$ This table has a purely descriptive function: the selection criterion is not based on this but based on the MBIC, MAIC, and MQIC statistics.

${ }^{3}$ The known cyclical motives, as pointed out by Arora et al. (2013).

${ }^{4}$ Another model, without GDP Growth, can be seen in the Appendix as well, and the same relationship is found.
} 
we explore the effects of capital controls on FDI, Debt and Portfolio Equities accounts. What we find there is that this positive dynamic in NFA account is possibly driven by positive results in the portfolio equities account, once the controls mitigate its liabilities.

The results refer to Magud et al. (2018) and Parischa (2017), as well as to literature where capital controls are seen as stabilizers: Ostry et al. (2010) and Forbes et al. (2015). A more recent study is Wang and Wu (2018) who observe capital controls as countercyclical, responding to external shocks as well and altering portfolio flows. On the other hand, the result differs from Fernandez et al. (2015). In this latter, they find almost none evidence linking capital controls to variables such as output, current account, and exchange rates: capital controls would be acyclical. We imagine that such difference lies in different approach taken by Fernandez: a static one, with a higher and different set of countries. 
Figure 2.1: Orthogonalized IRF - 95\% IC; Impulse- Response. Left: ImpulseControls on Inflows; Response- Net External Position. Right: Impulse-Current Account; Response- Controls on Inflows.
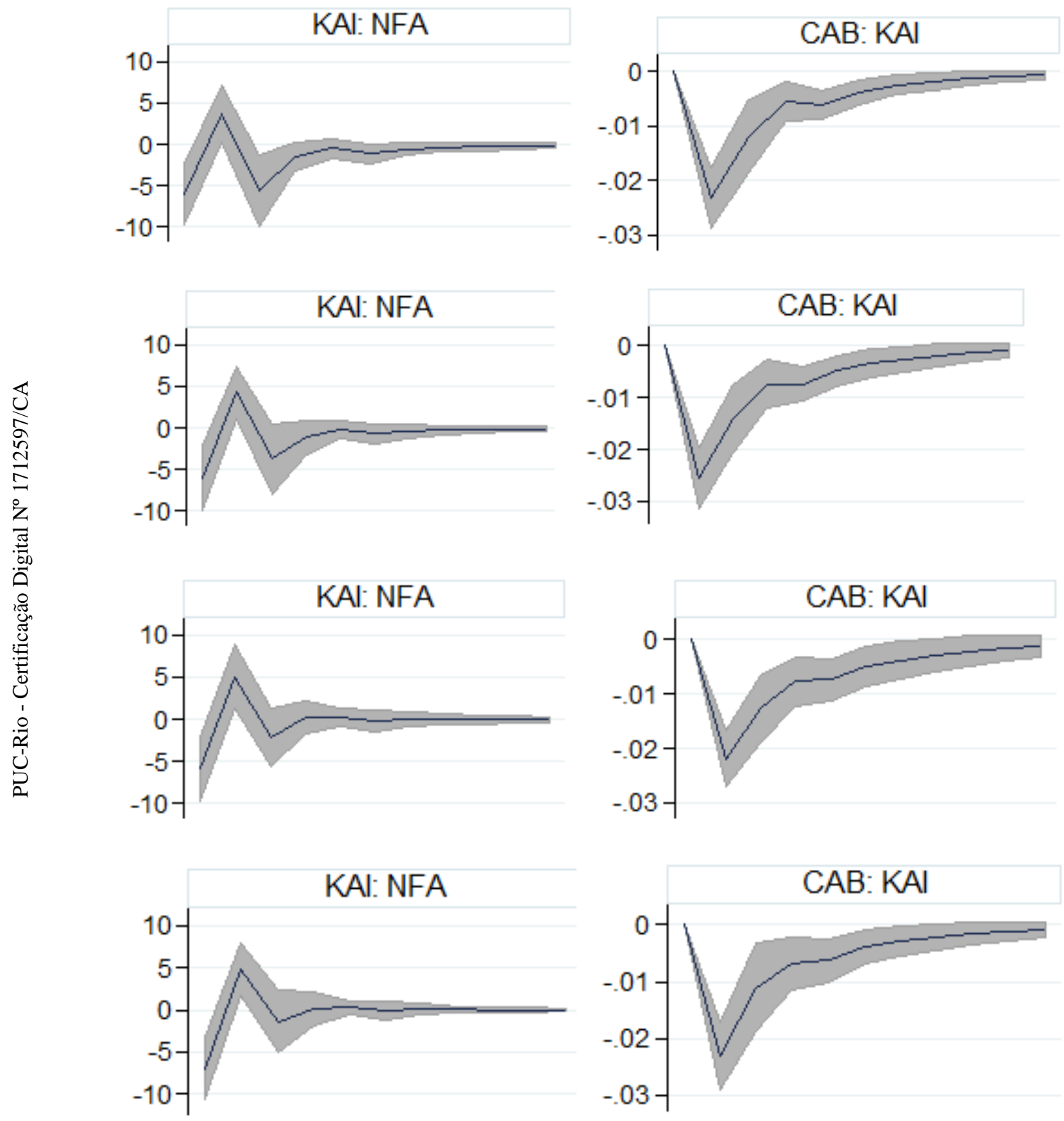


\section{2}

\section{Capital Control Law of Motion}

In the previous section, we present evidence in which capital controls are responses to shocks in the current account. In this sense, capital controls would be the result of a stabilizing policy, as suggested by Jeanne and Korinek (2010). In view of this, it is pertinent to investigate how optimum these responses were. The present section aims to estimate a functional form that comes from the dynamics observed in the previous one. The interest in the remainder of the work will be to use such law for inferring the welfare improvements that an economy under capital control may have.

How to obtain a capital control law of motion? Observing the impositions of capital controls made by the countries alludes what would be the form of these, in order to have the best fit in the data. At the moment, however, in the panel we have several countries, with several data: should we estimate an aggregate capital control law? But if so, how to make analyzes, simulations, to answer questions about its optimality? In view of this, it seems reasonable to choose one of these countries in order to proceed. The country chosen is Brazil. The reason for the choice is due to the variety, amplitude, and recurrence in which Brazil used capital controls vis-à-vis the other countries since the 1990s (Fernandez et al. (2015)). In addition, Souza-Sobrinho (2011) shows that the Brazilian economy, even in an $\mathrm{RBC}$ environment, can replicate some dynamics presented in many emerging countries.

\subsection{1}

\section{Estimating Euler Equation}

A first step is to capture a proxy that represents the capital control data in Brazil. Since, in the majority, these controls were done by means of taxation, one can think of a distorting Euler Equation for the Brazilian economy through a tax that modifies the agents intertemporal choice. So, to obtain this proxy we estimate Euler's Equation without any distortion and we take its residuals, simulating the imposition of capital controls.

Using the Consumption-Based Asset Pricing Model, as discussed in Campbell (2003), the agent faces the following problem:

$$
\max _{c_{t}, q_{t}} \quad \mathbb{E}_{t}\left[\sum_{t=0}^{\infty} \beta^{t} U\left(c_{t+i}\right) \mid \Psi_{t}\right]
$$

s.t.:

$$
c_{t}+p_{t} q_{t}=r_{t} q_{t-1}+w_{t}
$$

Where $c_{t}$ is the consumption, $q_{t}$ the assets, $w_{t}$ the initial wealth of the agent, $r_{t}$ 
the interest rates and $\Psi_{t}$ the set of agent information in the period $t$. Solving this problem for to $c_{t}$ and $q_{t}$, we have the following Euler Equation:

$$
\mathbb{E}_{t}\left[\beta \frac{r_{t+1}}{p_{t}} \frac{U_{c, t+1}}{U_{c, t}} \mid \Psi_{t}\right]-1=0
$$

The estimation will be accomplished by assuming a power-utility function :

$$
U\left(c_{t}\right)=\frac{c_{t}^{1-\gamma}}{1-\gamma}
$$

The choice of this functional form alludes to the existence of a representative agent whose consumption is time separable. This separability makes estimation more immediate. In addition, power-utility is invariant in scale, which leaves it consistent with the fact that the risk premium does not vary greatly over time (under constant returns) even with increasing degree of wealth and economy (Campbell (2003)). Thus, we can rewrite equation (3-4) as: ${ }^{5}$

$$
\mathbb{E}_{t}\left[\beta R_{t+1}\left(\frac{c_{t+1}}{c_{t}}\right)^{-\gamma} \mid \Psi_{t}\right]-1=0
$$

The data used to perform the estimation were:

$R_{t+1}:\left(1+\frac{\text { Treasury }}{C P I}\right)$, from FRED-St.Louis, for the Brazilian Economy;

$c_{t}$ : Index of consumer goods semi-durable and non-durable, seasonally adjusted (IPEA).

The observed data is monthly, from 1995.1 to 2015.12.

The estimation was done with two sets of instruments, lags of the variables in question. In the first set of instruments, we have two lags of the variables; in the second, four. The purpose of this was to verify if there would be much difference among the procedures.

Table 2.2 looks informative. ${ }^{6}$ The coefficients are within the expected: $\beta<1$ and $\gamma$ in the range suggested by the literature: Hall (1988), Campbell (2002) and Cochrane (2009).

A first exercise to be done is to take the generated proxys (residues), capital controls, and make an OLS of them on the Brazilian external accounts, taken from Lane et al. (2015). ${ }^{7}$

${ }^{5}$ Simplifying, take $\frac{r_{t+1}}{p_{t}}=R_{t+1}$.

${ }^{6}$ Estimation weighting matrix: HAC (Bartlett kernel, Newey-West fixed bandwidth = 5.0000) and Standard errors covariance computed using HAC weighting matrix (Bartlett kernel, Newey-West fixed bandwidth $=5.0000)$.

${ }^{7}$ See Appendix to understand such construction. 
Table 2.2: Estimating Euler Equation - GMM.

\begin{tabular}{|c|c|c|c|c|}
\hline \multicolumn{5}{|l|}{ Few Instruments } \\
\hline & Coefficient & Std. Error & t-Statistic & Prob. \\
\hline$\beta$ & 0.814682 & 0.025846 & 31.52029 & 0 \\
\hline$\gamma$ & 14.19423 & 6.2183 & 2.282654 & 0.0234 \\
\hline \multirow[t]{2}{*}{ S.E. of regression } & 0.696322 & Sum squared resid & & 109.5794 \\
\hline & & $\operatorname{Prob}(J$-statistic $)$ & & 0.0741 \\
\hline \multicolumn{5}{|l|}{ More Instruments } \\
\hline & Coefficient & Std. Error & t-Statistic & Prob. \\
\hline$\beta$ & 0.810229 & 0.017632 & 45.95154 & 0 \\
\hline$\gamma$ & 14.6401 & 3.529085 & 4.148411 & 0 \\
\hline \multirow[t]{2}{*}{ S.E. of regression } & 0.497126 & Sum squared resid & & 51.651 \\
\hline & & Prob(J-statistic) & & 0.283464 \\
\hline
\end{tabular}

Table 2.3: OLS: Residuals - Accounts

\begin{tabular}{lll}
\hline \hline Variables & Residuals $(1)$ & Residuals $(2)$ \\
& & \\
\hline Current Account & $-0.00352^{* *}$ & $-0.00267^{*}$ \\
& $(0.00102)$ & $(0.00185)$ \\
Net External Position & -0.000202 & -0.000221 \\
& $(0.000183)$ & $(0.000187)$ \\
Constant & $-0.125^{* * *}$ & $-0.107^{* * *}$ \\
& $(0.0323)$ & $(0.0356)$ \\
& & \\
\hline Observations & 197 & 185 \\
R-squared & 0.019 & 0.013 \\
Robust standard errors in parentheses & & \\
$* * * \mathrm{p}<0.01, * * \mathrm{p}<0.05,{ }^{*} \mathrm{p}<0.1$ & & \\
\hline
\end{tabular}

The regression in Table 2.3 focus on the significance and sign of the results. As in the previous section, there is a negative relationship between the current account and capital controls, relating to the result found earlier, where the disturbances in the current account induce the latter.

In order to proceed, however, we need to have some notion of the functional form presented between the variables - in particular, between the capital controls and the current account. From this, we have Figure 2.2, which exposes the negative relation between capital control and the situation of the current account in the Brazilian economy through a non-parametric approach. This estimation was made taking the Residuals (1) and the Brazilian current account between 1995 and 2015 (in Billions), monthly, considering the locallinear nonparametric method described in Racine and Li (2004). ${ }^{8}$

One way of thinking about a law of motion that governs capital control

${ }^{8}$ Optimal bandwidths automatically computed. 
Figure 2.2: Non-Parametric Regression: Capital Controls x Current Account

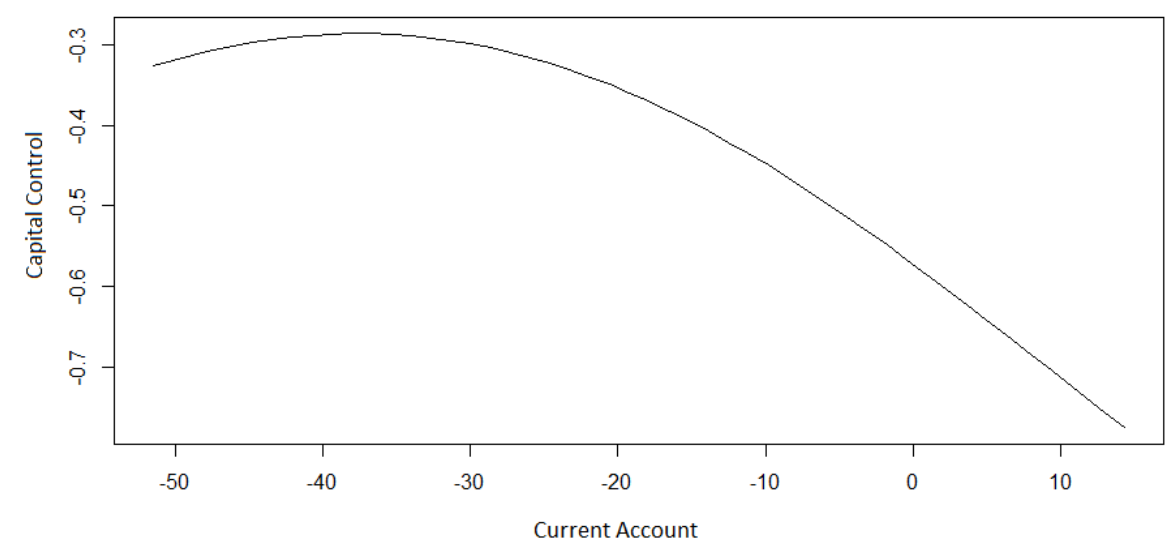

is provided by Kitano (2011):

$$
T(d)=\frac{\tau}{2}\left(d_{t}-\bar{d}\right)^{2}, \quad \text { s.t. } \quad \tau>0
$$

Where $d_{t}$ is the debt-output stock of the economy, and $\bar{d}$ its steady state.

The functional form (3-6) has two attractive properties: it incorporates a dynamic component in capital control, which allows its analysis in a temporal dimension, and still relates it to the "degree" of domestic economy indebtedness. This last point is crucial since there is a relation between the debt of an economy and its current account. Schmitt-Grohé and Uribe (2017) show how a sequential budget constraint of type $c_{t}+p_{t} q_{t}=r_{t} q_{t-1}+w_{t}$ can be manipulated until we obtain the following relation for the current account and debt: ${ }^{9}$

$$
c a_{t}=-\left(d_{t}-d_{t-1}\right)
$$

These relations become useful to propose a capital control law of movement for the Brazilian economy. Using (3-6) and (3-7), we suggest the following format for capital control here:

$$
t_{t}=\bar{t}+\left(e^{\psi\left(d_{t}-d\right)}-1\right)
$$

This law of motion is quite similar to that one proposed by Kitano (2011), but with a constant, which will be calibrated for some IOF values on fixed income and equities in Brazil, found in Pereira da Silva and Harris (2013). ${ }^{10}$

\footnotetext{
${ }^{9}$ Under certain transversality conditions in $q_{t}$, where this is thought as debt.

${ }^{10}$ This cyclical component of equation (8) can also be seen as a relation of the risk premium of the economy and the capital flow - a premium that feeds the inflows per se, as outlined in the Introduction.
} 
We then submit equation (3-8) to the data to see if they fit in nonlinear regression, just correcting for heteroskedasticity. ${ }^{11}$ We use here two ways of obtaining capital control by GMM - one with fewer and other with more instruments (Residuals (1) and Residuals (2), respectively).

A first concern that arises when estimating this functional form is its potential endogeneity: even though the residuals are a variable that reflects capital controls, not capital controls per se, this is not enough to eliminate potential endogeneity. This endogeneity can happen due to an omitted variable, which would be over/underestimating the coefficient $\psi$, or also through a simultaneity between the residues/capital controls and the current account.

To overcome these problems, we first performed a Durbin-Wu-Hausman test to observe the consistency of the estimator, not rejecting the null hypothesis where the estimator is consistent. As the framework occurs in a non-linear environment, we can generalize this test by the procedure presented in Lochner and Moretti (2015), and the result remains. Finally, we test some more controls that could be biasing the coefficient in question. The only control that can significantly modify the structure of the coefficient $\psi$ was the NFA. Likewise, the model was again submitted to the endogeneity test, where the null hypothesis was not rejected.

Table 2.4: Nonlinear Regression Model.

\begin{tabular}{|c|c|c|c|c|}
\hline & \multicolumn{4}{|c|}{ Model (1) } \\
\hline & \multicolumn{2}{|c|}{ Residuals (1) } & \multicolumn{2}{|c|}{ Residuals(2) } \\
\hline & Only CAB & Plus NFA & Only CAB & Plus NFA \\
\hline CAB Coefficients & $0.00395^{* * *}$ & $0.00124^{* * *}$ & $0.00328^{* * *}$ & $0.00118^{* * *}$ \\
\hline Standard Errors & $(0.00211)$ & $(0.00198)$ & $(0.00271)$ & $(0.00147)$ \\
\hline Observations & 197 & & 185 & \\
\hline \multirow[t]{4}{*}{ R-Squared } & 0.017 & 0.015 & 0.011 & 0.01 \\
\hline & \multicolumn{4}{|c|}{ Model (2) } \\
\hline & \multicolumn{2}{|c|}{ Residuals (1) } & \multicolumn{2}{|c|}{ Residuals(2) } \\
\hline & Only CAB & Plus NFA & Only CAB & Plus NFA \\
\hline CAB Coefficients & $0.00283^{* * *}$ & $0.00103^{* * *}$ & $0.00221^{* * *}$ & $0.00110^{* * *}$ \\
\hline Standard Errors & $(0.00283)$ & $(0.00175)$ & $(0.00271)$ & $(0.00355)$ \\
\hline Observations & 197 & & 185 & \\
\hline $\begin{array}{l}\text { R-Squared } \\
* * * \mathrm{p}<0.01, * * \mathrm{p}<0.05 * * \mathrm{p}<0.1\end{array}$ & 0.015 & 0.014 & 0.012 & 0.011 \\
\hline
\end{tabular}

Table 2.4 reproduces the results with data from the Brazilian economy. The coefficient of interest is $\psi$, which is significant and in the expected range, even after the control, in the different specifications for the external accounts: Model (1) and Model (2). The results are similar; $\psi$ here can be thought of as the sensitivity of inflows to the risk premium of the economy and provides us with the relation debt (current account) and the imposition of capital controls. ${ }^{12}$

\footnotetext{
${ }^{11}$ The relevant correction for generated variables as can be seen in Chen et al. (2018).

${ }^{12}$ Confidence intervals of these estimates by means of 100 replications through bootstrap are adequate.
} 


\section{3}

\section{General Model}

\section{1}

\section{Discussion}

A version of the Real Business Cycle model is proposed, simulating a small open economy (SOE). The model has a mass of identical domestic agents, with preferences taking into account consumption and labor, having access only to a single asset (debt). The economy also has firms, which produce a single good to be consumed or reinvested, choose capital and demand work. There is also a government, which taxes the agent through a capital control and returns it through transfers. Finally, the model has the rest of the world, which lends to the domestic economy.

The model is then adapted, including a capital control (taxation) on the domestic debt stock, which attempts to mitigate a scenario of overborrowing. ${ }^{1}$ In this sense, capital controls become countercyclical. Moreover, the economy has domestic interest rates increasing in its debt level, although the agents do not realize such fact. This phenomenon, in turn, creates an externality in the economy. The current account, here, is not enough to prevent excessive debt and the "opening" of the risk premium when the economy is subject to an adverse shock. This is due to the absence of an explicit restriction on indebtedness and mechanisms that internalize such friction by the agents. Capital control, however, is precisely the variable that does this, once it immediately makes the debt more expensive.

As already mentioned, the fact that interest rates are increasing in the degree of indebtedness of the domestic economy refers to a premium of risk in it. The existence of this risk premium in emerging economies is already observed and addressed by the literature. Specifically, Arellano (2008) relates the external debt of emerging countries, plus the possibility of default, with a sudden rise in domestic interest rate, reinforcing the results found in Aguiar and Gopinath (2007). In this same sense, Broner et al. (2013) also captures this interest-debt friction. Senhadji (1994) inaugurates a tradition of dealing with emerging economies highlighting this same relationship, followed by Mendoza

${ }^{1}$ See Appendix. 
et al. (2000), Nason and Rogers (2006), Garcia-Cicco and Uribe (2010) and Seoane (2015). Also, related to this phenomenon we have Figure 3.1: it plots the external debt of emerging economies and their spread through an average of 15 years.

Figure 3.1: External Debt as share of GNI to Emerging Markets and Emerging Markets from Latin America (Source: OECD).
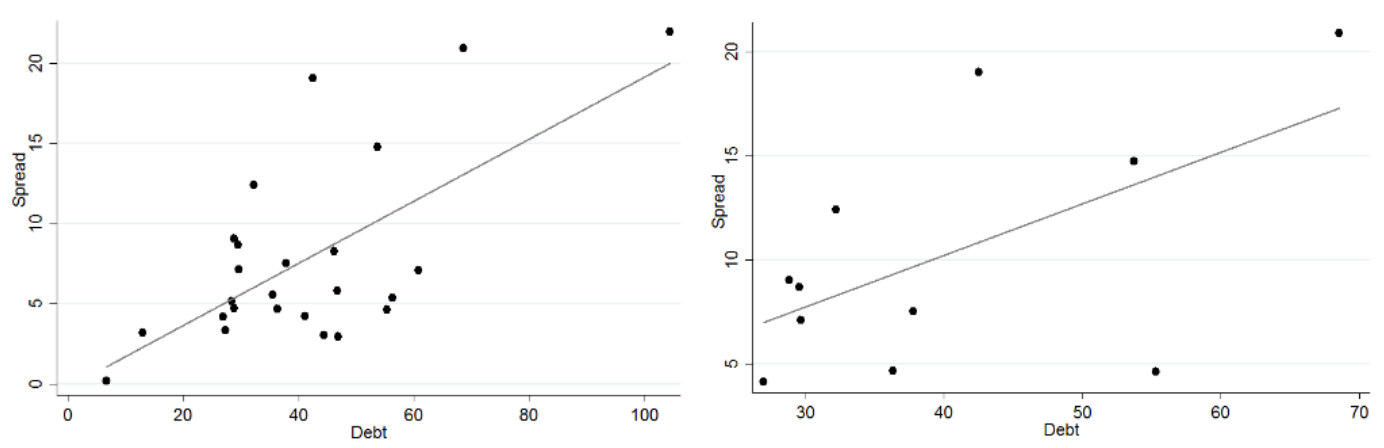

Thus, we present a framework that aims to study the imposition of capital controls in economies where interest-debt friction is not internalized by agents. This phenomenon has important implications since the non-perception of it leads to a kind of common tragedy: debt becomes more expensive as agents take more debt. This creates a pernicious dynamics, especially when agents tend to increase their debts in order to soften consumption after a negative shock in the output. Such effects will create a scenario for the implementation of taxation, a capital control.

The adaptation of an RBC model to an open economy dates back to Mendoza (1991), which sought to understand business cycle patterns in postwar Canada. He was followed by Backus and Kehoe (1992), which adapts a model of two countries with a similar intention. Furthermore, Schmitt-Grohé and Uribe (2003) and Neumeyer and Perri (2005) take the same framework for other purposes. The use of such a model in the present work, however, is intended to exploit a real friction - increasing interest in the debt of the economy - which emerging economies, especially those with problems in their external accounts, tend to have. Here, the relatively simpler environment will allow to obtain and analyze a closed form for capital controls.

More specific use of RBC models in emerging economies are found in Aguiar and Gopinath (2007) and Garcia-Cicco and Uribe (2010). This last work shows how the use of RBC is able to illustrate well the dynamics of macroeconomic variables in emerging markets (in this case Argentina and 
Mexico) when some frictions are incorporated, among which there is the interest-debt friction brought during this current work.

Finally, the model will be calibrated for the Brazilian economy. There are a few papers relating to RBC and Brazil. Two efforts in this direction are Kanczuk (2004) and Souza-Sobrinho (2011). The first one analyzes the role of interest rates in fluctuations of the domestic product between 1980 and 2001. The second paper, in turn, has similar intent and adapts the model of working capital proposed by Neumeyer and Perri (2005). However, reinforcing, our choice for the Brazilian economy in order to proceed with the exercise and the simulations is due to two points: Brazil was the country that most implemented capital controls in the last twenty years (Fernández et al. (2015)); Brazil can replicate well the economic dynamics observed in emerging economies (SouzaSobrinho (2011)). In this regard, it should be emphasized that the choice for the Brazilian economy here has no specific intention.

\section{2}

\section{Model}

\section{Agents and Firms}

The agents problem is given by:

$$
\begin{gathered}
\max _{c_{t}, h_{t}} \mathbb{E}_{t} \sum_{t=0}^{\infty} \beta^{t} U\left(c_{t}, h_{t}\right) \\
c_{t}-d_{t} \leq w_{t} h_{t}+d_{t-1}\left(1+r_{t-1}\right)\left(1+t_{t-1}\right)+s_{t}
\end{gathered}
$$

Where $c_{t}$ is the consumption, $d_{t}$ is the debt, $w_{t}$ is the wage, $h_{t}$ is the hours worked, $r_{t}$ the domestic interest rate and $s_{t}$ the transfers. The capital law of movement and the production function follow by equations (2-3) and (2-4), respectively:

$$
\begin{gathered}
k_{t+1}=i_{t}+(1-\delta) k_{t} ; \\
y_{t}=A_{t} k_{t}^{\alpha} h_{t}^{1-\alpha} ;
\end{gathered}
$$

Where $i_{t}$ is the investment and $\delta$ is the depreciation rate. The firms, in turn, will solve:

$$
\max _{k_{t}, l_{t}} y_{t}-\left[w_{t} l_{t}+i_{t}+\frac{\phi\left(i_{t}-k_{t}\right)^{2}}{2}\right]
$$

Where $\phi$ is the parameter associated to the capital adjustement cost. Also, a 
stochastic process for the technology is taken:

$$
\ln A_{t+1}=\rho \ln A_{t}+\epsilon_{t+1} ; \quad \epsilon_{t+1} \sim \operatorname{NIID}\left(0, \sigma^{2}\right), \quad t \geq 0
$$

As usual in the International literature, Greenwood-Hercowitz-Huffman preferences are taken. Their use implies that the marginal rate of substitution between consumption and leisure depends only on labor. In other words, GHH preferences deliver a labor supply that is income inelastic. In this sense, the consumption growth depends not only on interest rates but also on movements in equilibrium employment. Such relation is important in order to provide stylized facts in emerging market economies. So, the utility function is:

$$
U\left(c_{t}, h_{t}\right)=\frac{\left(c_{t}-\omega^{-1} h_{t}^{\omega}\right)^{1-\gamma}-1}{1-\gamma}
$$

A condition of transversality for the indebtedness is imposed, which will be satisfied with equality in the families:

$$
\lim _{j \rightarrow \infty} \mathbb{E}_{t} \frac{d_{t+j}}{\prod_{s=1}^{j}\left(1+r_{s}\right)} \leq 0
$$

\section{Additional Structures:}

The domestic economy interest rate will have the following structure:

$$
r_{t}=r^{*}+p\left(d_{t}\right) \quad \text { s.t. } \quad r^{*}=\bar{r}+\epsilon_{t}^{r} ; \quad \epsilon_{t}^{r} \sim N I I D\left(0, \sigma_{r}^{2}\right), \quad t \geq 0
$$

Where $r^{*}$ is the external interest rate, which may be subject to some shock $\epsilon_{t}^{r}$. This specification, as mentioned, introduces a friction, which opens space for an active intervention by the local authority: agents will optimize taking $p\left(d_{t}\right)$ as given, despite the fact that this component is endogenous. This last one still has the following features:

$$
p^{\prime}\left(d_{t}\right)>0 ; \quad p^{\prime}(0)=0 ; \quad p(0)=0
$$

Following the literature (Nason and Rogers (2006); Lubik (2007); Seoane (2015)) we can specify this function in allusion to the risk premium of the economy as:

$$
p\left(d_{t}\right)=\left(e^{\zeta\left(d_{t} / y_{t}-d \overline{/} y\right)}-1\right)
$$


Meanwhile interest rates are increasing in the economy's degree of indebtedness, and through the relationship between the current account and debt, a transmission channel arises and it can be exploited through an appropriate tax rates.

Finally, we will have a law for capital control that will incorporate debt and current account, that is given by equation (2-8):

$$
t_{t}=\bar{t}+\left(e^{\psi\left(d_{t}-d\right)}-1\right)
$$

Taking its partial derivate:

$$
\frac{\partial t_{t}}{\partial d_{t}}=\psi e^{\psi\left(d_{t}-d\right)}
$$

Which is also always positive as long as $\psi$ be positive. It follows, then, that such law of motion will also be decreasing in the current account as well.

The result presented in $(*)$ refers to the negative relationship between the current account and the capital controls put under investigation and found in the previous chapters. In particular, the fact that controls act in a stabilizing way when facing shocks. In the following sections, it will be verified that such countercyclical effects can be reproduced in the presented model, capturing these dynamics with both the current account and the output. 


\section{4}

\section{Welfare}

Until now the work exhibited systematic relations of capital controls with external accounts and, based on this, estimated a law of motion for the capital control in Brazil. In this chapter, we are going to simulate the RBC model under different specifications for capital control's law and investigate its features.

\section{1}

\section{Welfare Analysis}

The welfare analysis will be carried out by simulating and comparing the RBC model in two main scenarios: economy with no capital control and economy with the Ad-hoc capital control. The parameters used are found in Table $4.1{ }^{1}$ and the economy is adjusted for Brazil with quarterly data.

\begin{tabular}{lll}
\multicolumn{3}{c}{ Table 4.1: Parameters. } \\
\hline \hline & Value & Source \\
\hline$\gamma$ & 1.3 & Santos et al. (2011) \\
$\omega$ & 2 & Santos et al. (2011) \\
$\alpha$ & 0.448 & Santos et al. (2011) \\
$\bar{r}$ & 0.0074 & Santos et al. (2011) \\
$\sigma_{r}^{2}$ & 0.19 & Santos et al. (2011) \\
$\delta$ & 0.015 & Santos et al. (2011) \\
$d^{*}$ & 0.5 & Costa (2016) \\
$\phi$ & 0.1 & Costa (2016) \\
$\rho$ & 0.25 & Costa (2016) \\
$\sigma$ & 0.25 & Costa (2016) \\
$\psi$ & 0.0012 & Estimated. \\
$\zeta$ & 0.0395 & Estimated. \\
\hline
\end{tabular}

The analyzes and simulations that follow explain the reactions of the domestic variables against a shock in the output, trying to simulate, in some sense, the process of deterioration in the current account. Nevertheless, equation (3-6) introduces a stochastic component in the external interest rates. $^{2}$ Such component allows external shocks in the model, which fit better

${ }^{1}$ The interest-debt elasticity, $\zeta$ was obtained by means of Bayesian estimation. See Appendix.

${ }^{2} r^{*}=\bar{r}+\epsilon_{t}^{r}$. 
the statistical moments considering the real data. Although we did not draw explicit considerations of the international interest rates shock here, Table 4.3 presents some relationships of the RBC adapted model with the empirical data using domestic and external interest rate shocks. ${ }^{3}$

The empirical moments were taken from Souza-Sobrinho (2011), except for: Risk Premium - Santos et al. (2011); the debt was taken from the External Balance Account (FRED) and compared to the first difference of the Brazilian GDP (FRED); capital controls data were extracted from the empirical part and compared with the first GDP difference (FRED).

The statistical moments presented in Table 4.3 incorporate the domestic and external interest shock. First of all, there is greater volatility in consumption and investment relative to the data - usual in emerging economy models. Regarding to investment, this is possibly due to the difficulty in estimating the relevant capital adjustment cost. As for consumption, this is amplified by the use of GHH preferences: without them, however, consumption may be less volatile than output, contrary to the empirical evidence. Capital controls and debt between the $A d$-hoc model and the data are similar. At last, capital controls are negatively correlated to the output in model and in the data.

In Table 4.2, in turn, we emphasize that both models, even with the different specifications for capital controls, in fact, replicate the result of the negative relation with the external accounts of the economy, found in the previous chapters. This matters in the sense that it confers a fit to the model.

Table 4.2: Correlations

\begin{tabular}{lll}
\hline \hline Correlations & & \\
\hline Capital Control & Trade Balance-GDP & Current Account-GDP \\
Ad-hoc & -0.4963 & -0.5521 \\
& & \\
\hline
\end{tabular}

\footnotetext{
${ }^{3}$ The importance of introducing the external shock to evaluate the fit of the model to the data is in Nelson-Sobrinho (2011).
} 


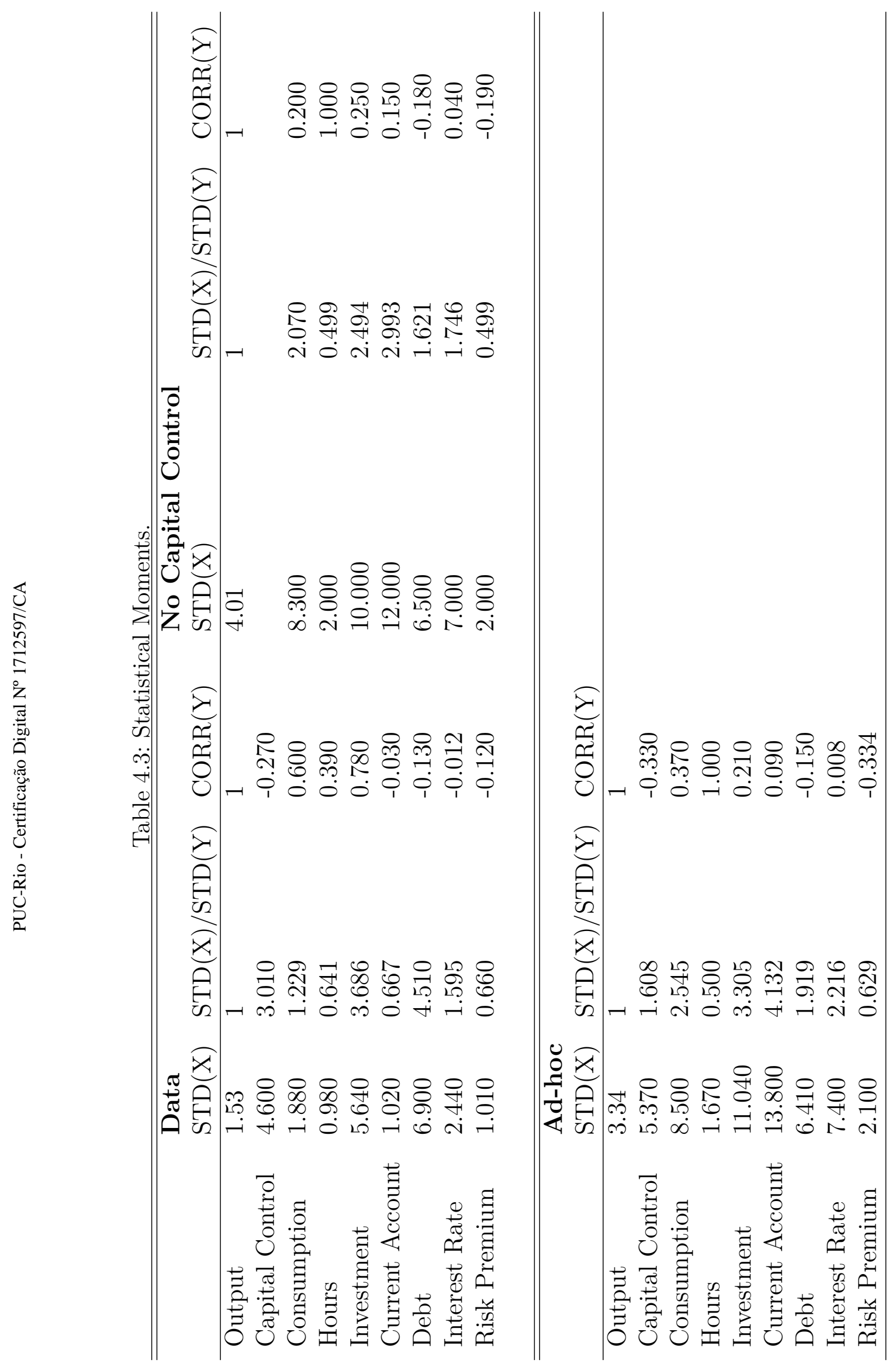


In Figure 4.1, we see three kinds of IRF's: the black, green and blue. The black IRF's refer to the responses in an environment with no capital control. The green IRF's report the response in the economy under capital control when $\bar{t}=0.01$, meanwhile the green IRF's refer to this same economy with $\bar{t}=0.06$. Why such a distinction? This component of capital control, $\bar{t}$, refers to the discretionary component in the imposition of capital control. The idea is to replicate, to some extent, the IOF taxes in Brazil, as pointed out by Pereira da Silva and Harris (2013). Following this paper, we consider 0.01 as its minimum value, and 0.06 its maximum. We highlight these two calibrations here in order to exploit some discrepancy difference in the responses - we find that there is not.

As we can see in Figure 4.1, the economy that operates with capital controls, which cause agents to internalize the interest-debt ratio to some extent, makes the economy more stable, specially through debt, interest rates and the risk premium. In particular, the household's debt response, which is brought here as the epicenter of internal disturbances, is less volatile in the economy with capital controls. Also, in the economy under capital controls, the impulse-response functions admit a greater convexity, returning the variables to their respective stationary states more quickly. At the same time, the working hours are the same among the models, as should be expected using GHH preferences. The output response follows a trajectory only with marginal distinctions, although its components change on a larger scale: in particular, there is a substantial difference in the dynamics of investment and capital between them. At the same time, consumption and investment are severely penalized shortly after the shock. 
Figure 4.1: Black: No capital control; Green: Ad-hoc capital control; Blue: Adhoc with $\bar{t}=6 \%$. Negative Domestic Shock.
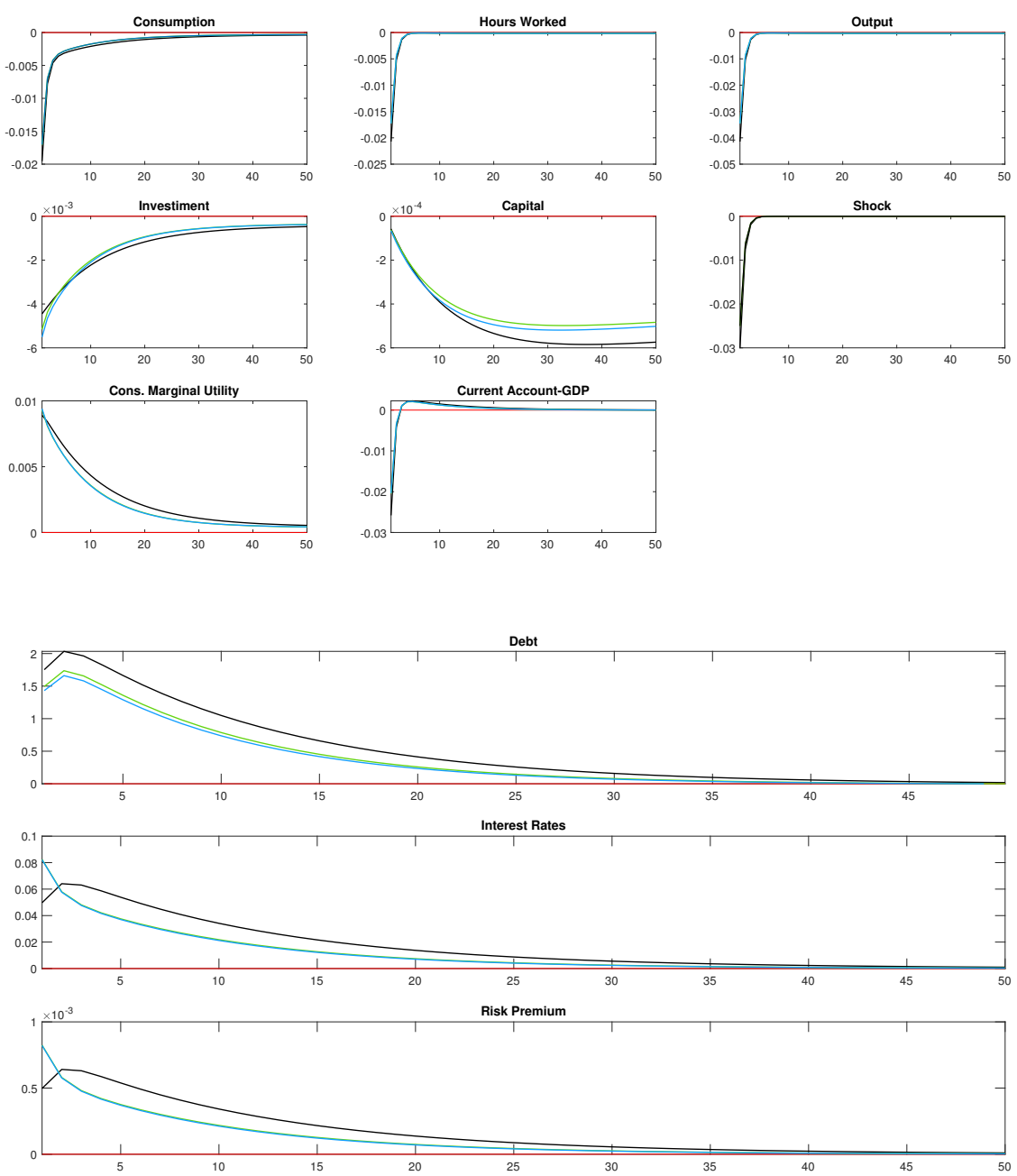
In a more analytical way, it is possible to verify some improvement of welfare in the transition path in the economies under capital controls relative to the economy free of controls. This is done by computing the average deviation from the long-term trend of the economy (simulated for a thousand periods) for two key variables here: consumption and debt. Regarding consumption, the deviation from the long-run trajectory for the Ad-hoc's economy is $84 \%$ of the deviation from the uncontrolled (capital) economy. Regarding debt, the deviation from the long-term path to the Ad-hoc's economy is $70 \%$ of the deviation from the uncontrolled economy.

One can also approach welfare variation in another way: if we subject economies to the same parameters, we observe two distinct stationary states, one for the economy without capital control and another for the capitalcontrolled economies. ${ }^{4}$

Thus, we can compare the welfare variation in the steady state as follows:

$$
\mathbb{E}_{t} \sum_{t=0}^{\infty} \beta^{t} \frac{\left(c_{t}\left(1+\frac{\Lambda^{f c m}\left(y_{t}, r_{t}, d_{t}, h_{t}\right)}{100}\right)-\omega^{-1} h_{t}^{\omega}\right)^{1-\gamma}-1}{1-\gamma}=v\left(y_{t}, r_{t}, d_{t}, h_{t}\right)^{c c}
$$

Where $v\left(y_{t}, r_{t}, d_{t}, h_{t}\right)^{c c}$ is the value of utility under capital control.

Table 4.4: Welfare changes in the steady relative to the economy under capital control.

\begin{tabular}{lcccccc}
\hline \hline $\bar{t}$ Value & 0.01 & 0.02 & 0.03 & 0.04 & 0.05 & 0.06 \\
& & & & & & \\
\hline Welfare Change & 0.18 & 0.095 & 0 & -0.105 & -0.18 & -0.25
\end{tabular}

The Table 4.4 presents the $\Lambda^{f c m}$ (.) for six values of $\bar{t}^{5}$ As we can see, changing the average tax, $\bar{t}$, in Ad-hoc's to higher levels, the economy will pass no to have welfare gains in comparison to the economy with free of capital controls. In particular, there is, in fact, a welfare loss when we start to calibrate $\bar{t} \geq 3 \%$, relative to the free economy - this welfare loss would continue to increase as long as $\bar{t}$ increases. This is very important because it introduces parsimony in the benefits of introducing capital controls heuristically, without considerations of the particularities to which the economy is subjected. So, even though the capital control may work as a stabilizer for the economy,

${ }^{4}$ The difference of this exercise in relation to the previous one is that in this first the calibration of the intertemporal discount of the free economy was adjusted to obtain the same of the steady state as the controlled economies, allowing the relevant calculation of welfare variation along the transition dynamics.

${ }^{5}$ Some changes may seem to extreme for an RBC model, but similar results are found in Schmitt-Grohé and Uribe (2016). 
your imposition may lead to a loss of welfare in the steady state (and possibly through all the dynamic path).

\section{2}

\section{Robustness Results}

In order to better verify the results of economies under shock in the output, we make new estimates based on different values for the parameter $\zeta$, which governs the sensitivity of domestic interest rates to the debt. This parameter is important since besides modifying the transition dynamics, it plays a fundamental role in the stationarity of the model. We then take its minimum value as 0.01 and its maximum value as $0.08 .^{6}$ From this, we have a range when we variate the IRFs, which can be seen in Figure 4.2. As it is clear, the above conclusion holds: capital-controlled economies are less volatile to shocks, especially when subjected to the optimal capital control.

At the same time, we can check the stability related to the estimated $\psi$ coefficient. However, since its standard errors are small, we are just extrapolating the coefficient centred in 0.0012 to 0.01 and to 0.0001 . The results follow in Figure 4.3. Again, the results do not change too much, even under the high distortion in the estimated coefficient $\psi$, when compared to Figure 4.2. ${ }^{7}$ A possible reason for this is that Ad-hoc's capital control is more driven by the discretionary component, $\bar{t}$, than for its cyclical component and, for that reason, we do not observe higher changes when we vary $\psi$ in marginal dimensions.

${ }^{6} \mathrm{CI} 90 \%$, Bayesian Estimation.

${ }^{7}$ If we had just used the confident interval from Table 3.5 we would have only marginal changes in the range. 
Figure 4.2: Black: No capital control; Green: Ad-hoc capital control.
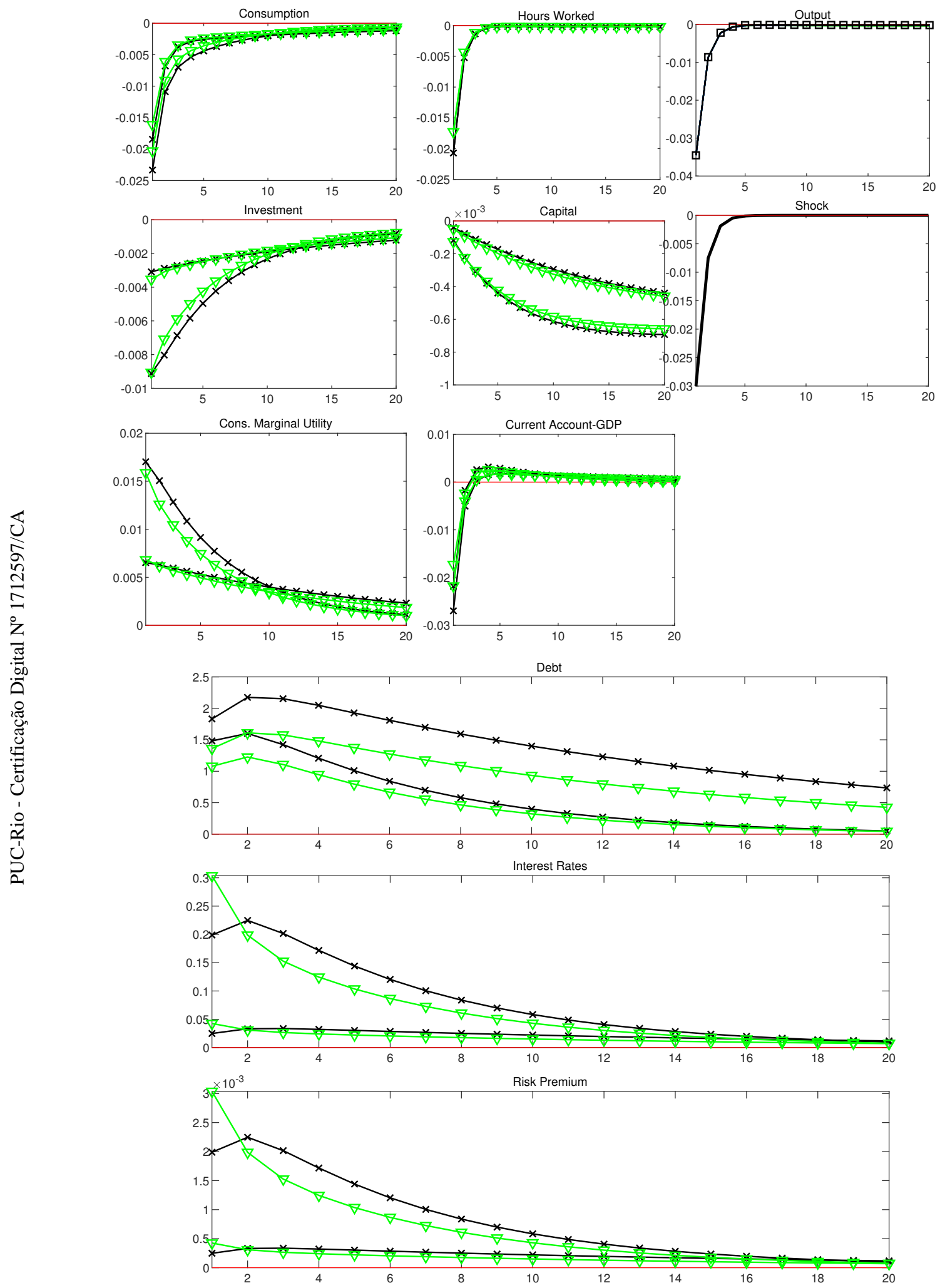
Figure 4.3: Black: Ad-hoc capital control changing $\psi$ between 0.0001 and 0.01; Green: Previous Ad-hoc capital control.
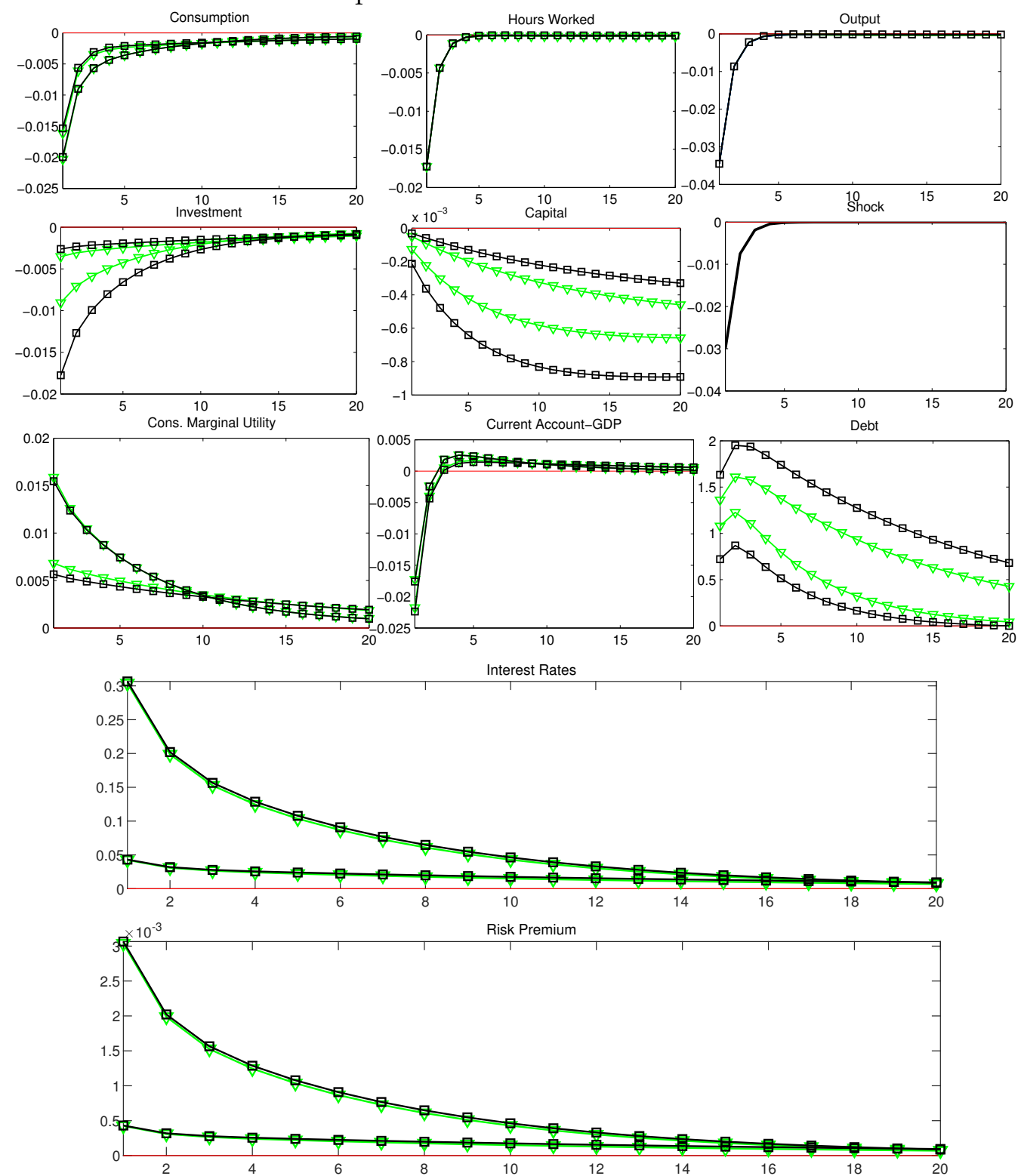


\section{5}

\section{Conclusions}

The work presents capital controls as countercyclical, being these ones conceived as responses to shocks in the current account. In addition, the work studies the extent to which such controls have been implemented in an optimal way for an economy with increasing interest rates in its degree of indebtedness.

Estimating a law of motion that captures the dynamics of capital controls in Brazil, the work compares an economy with and without such capital control. First, this exercise shows that the economy under capital control tends to be more stable when adjusted to provide the same stationary states. We also can see that the economy under capital controls may experiment an increase in its welfare level for some calibrations in its discretionary component, $\bar{t}$, but, at the same time, we show that beyond some level for $\bar{t}$ such welfare improvements are jeopardized. In this sense, we highlight that at excessive taxation, capital controls may lose its ability to generate welfare gains to the economy, which alludes to a certain precaution in the heuristic imposition of them.

Finally, the contributions of the work are again emphasized. Firstly, crossing different databases it seeks to extract systematic relations between capital controls and external accounts of LatAm countries. Moreover, with these data, it is estimated a law of movement of capital controls for the Brazilian. That way, the work tries to contribute with the idea of optimality in an emerging economy that imposes capital controls and is submitted to a real friction in its interest rates. 


\section{Bibliography}

Abrigo, M. R. and Love, I. (2016). Estimation of panel vector autoregression in stata. The Stata Journal, 16(3):778-804.

Aguiar, M. and Gopinath, G. (2007). Emerging market business cycles: The cycle is the trend. Journal of political Economy, 115(1):69-102.

Arellano, C. (2008). Default risk and income fluctuations in emerging economies. American Economic Review, 98(3):690-712.

Arellano, M. and Bover, O. (1995). Another look at the instrumental variable estimation of error-components models. Journal of econometrics, 68(1):29-51.

Arora, V., Habermeier, K., Ostry, J. D., and Weeks-Brown, R. (2013). The liberalization and management of capital flows: An institutional view. Revista de Economía Institucional, 15(28):205-255.

Backus, D. K. and Kehoe, P. J. (1992). International Evidence on the Historical Properties of Business Cycles. American Economic Review, 82(4):864-888.

Benigno, G. and Fornaro, L. (2014). The financial resource curse. The Scandinavian Journal of Economics, 116(1):58-86.

Broner, F. A., Lorenzoni, G., and Schmukler, S. L. (2013). Why do emerging economies borrow short term? Journal of the European Economic Association, 11(suppl_1):67-100.

Campbell, J. Y. (2002). Understanding Risk and Return. Journal of Political Economy, 104(2):298-345.

Campbell, J. Y. (2003). Chapter 13 Consumption-based asset pricing.

Canova, F. and Ciccarelli, M. (2013). Panel vector autoregressive models: A survey the views expressed in this article are those of the authors and do not necessarily reflect those of the ecb or the eurosystem. In VAR Models in MacroeconomicsNew Developments and Applications: Essays in Honor of Christopher A. Sims, pages 205-246. Emerald Group Publishing Limited.

Chamon, M. and Garcia, M. (2016). Capital controls in Brazil: Effective? Journal of International Money and Finance, 61:163-187. 
Chen, W., Hribar, P., and Melessa, S. (2018). Incorrect inferences when using residuals as dependent variables. Journal of Accounting Research, 56(3):751796.

Cochrane, J. H. (2009). Asset pricing: Revised edition. Princeton University Press.

Costa, S. (2016). Structural trends and cycles in a dsge model for brazil. Working Papers Series 434, Central Bank of Brazil, Research Department.

Farhi, E. and Werning, I. (2012). Dealing with the trilemma: Optimal capital controls with fixed exchange rates. Technical report, National Bureau of Economic Research.

Fernandez, A., Klein, M. W., Rebucci, A., Schindler, M., and Uribe, M. (2016). Capital control measures: A new dataset. IMF Economic Review, 64(3):548-574.

Fernández, A., Rebucci, A., and Uribe, M. (2015). Are capital controls countercyclical? Journal of Monetary Economics, 76:1-14.

Forbes, K., Fratzscher, M., and Straub, R. (2015). Capital flow management measures: What are they good for? NBER Working Papers 20860, National Bureau of Economic Research, Inc.

Garcia-Cicco, Javier, R. P. and Uribe, M. (2010). Real business cycles in emerging countries? American Economic Review, 100.5:2510-31.

Hall, R. (1988). The relation between price and marginal cost in u.s. industry. Journal of Political Economy, 96(5):921-47.

Hannan, S. A. (2018). Revisiting the Determinants of Capital Flows to Emerging Markets-A Survey of the Evolving Literature. International Monetary Fund.

Jeanne, O. and Korinek, A. (2010). Excessive volatility in capital flows: A pigouvian taxation approach. American Economic Review, 100(2):403-07.

Kanczuk, F. (2004). Real interest rates and Brazilian business cycles. Review of Economic Dynamics, 7(2):436-455.

Kitano, S. (2011). Capital controls and welfare. Journal of Macroeconomics, 33(4):700-710.

Lane, P. R., Milesi-Ferretti, G. M., et al. (2015). Global imbalances and external adjustment after the crisis. Central Banking, Analysis, and Economic Policies Book Series, 20:105-142. 
Lochner, L. and Moretti, E. (2015). Estimating and testing models with many treatment levels and limited instruments. The Review of Economics and Statistics, 97(2):387-397.

Lorenzoni, G. (2008). Inefficient credit booms. The Review of Economic Studies, 75(3):809-833.

Love, I. and Zicchino, L. (2006). Financial development and dynamic investment behavior: Evidence from panel var. The Quarterly Review of Economics and Finance, 46(2):190-210.

Lubik, T. (2007). Non-stationarity and instability in small open-economy models even when they are "closed". Economic Quarterly, (Fall):393-412.

Magud, N. E., Reinhart, C. M., and Rogoff, K. S. (2018). Capital controls: myth and reality. Annals of Economics and Finance, 19(1):1-47.

Mendoza, E. G. (1991). Capital controls and the gains from trade in a business cycle model of a small open economy. Staff Papers, 38:480-505.

Mendoza, E. G., Uribe, M., et al. (2000). Devaluation risk and the business-cycle implications of exchange-rate management. In Carnegie-Rochester Conference Series on Public Policy, volume 53, pages 239-296. Elsevier.

Nason, J. M. and Rogers, J. H. (2006). The present-value model of the current account has been rejected: Round up the usual suspects. Journal of International Economics, 68(1):159-187.

Neumeyer, P. A. and Perri, F. (2005). Business cycles in emerging economies: The role of interest rates. Journal of Monetary Economics, 52(2):345-380.

Ostry, J., Ghosh, A., Habermeier, K., Chamon, M., Qureshi, M., and Reinhardt, D. (2010). Capital inflows; the role of controls. IMF Staff Position Notes 2010/04, International Monetary Fund.

Pasricha, G. K. (2017). Policy rules for capital controls. Available at SSRN 3040092.

Pereira da Silva, L. A. and Harris, R. E. (2013). Dealing with the Challenges of Macro Financial Linkages in Emerging Markets. Dealing with the Challenges of Macro Financial Linkages in Emerging Markets.

Racine, J. and Li, Q. (2004). Nonparametric estimation of regression functions with both categorical and continuous data. Journal of Econometrics, 119(1):99-130. 
Santos, R., Souza-Sobrinho, N. F., Minella, A., Gouvea, S. N., and de Castro, M. R. (2011). SAMBA: Stochastic Analytical Model with a Bayesian Approach. $B C B$, page 139 .

Schmitt-Grohé, S. and Uribe, M. (2003). Closing small open economy models. Journal of International Economics, 61(1):163-185.

Schmitt-Grohé, S. and Uribe, M. (2016). Downward nominal wage rigidity, currency pegs, and involuntary unemployment. Journal of Political Economy, 124(5):1466-1514.

Schmitt-Grohé, S. and Uribe, M. (2017). Open economy macroeconomics. Princeton University Press.

Senhadji, A. S. (1994). Adjustment of a small open economy to external shocks.

Seoane, H. D. (2015). Near unit root small open economies. Journal of Economic Dynamics and Control, 53:37-46.

Souza-Sobrinho, N. F. (2011). The role of interest rates in the Brazilian business cycles. Revista Brasileira de Economia, 65(3):315-336.

Uribe, M. (2006). On overborrowing. American Economic Review, 96(2):417-421.

Wang, J. and Wu, J. (2018). The dilemma and international macroprudential policy: Is capital flow management effective? Working Paper.

Zeev, N. B. (2017). Capital controls as shock absorbers. Journal of International Economics, 109:43-67. 
A

\section{Overborrowing}

The overborrowing phenomenon in this economy can be seen shown using the final results found in Uribe (2006). Basically consists in explore the Euler's equation in an economy with no debt-elastic interest-rate where the agents internalize the externality vis-a-vis when they do not.

So, in the steady state, where $D^{*}$ is the debt's level we should satisfy the following equation, from Euler Equation when the agents do not internalize the effect of the debt on the interest rates:

$$
1=R\left(D^{*}\right) \beta
$$

On other hand, if the agents internalize, they face $R=R\left(d_{t}\right)$. In this case, the Euler Equation in the steady state will be:

$$
1-\frac{D^{* *} R^{\prime}\left(D^{* *}\right)}{R\left(D^{* *}\right)}=R\left(D^{* *}\right) \beta
$$

Where $D^{* *}$ is the level of steady state when the agents internalize the effect of debt on the interest rates. Since $R\left(d_{t}\right)$ increases in $d_{t}, R^{\prime}\left(D^{* *}\right)$ is positive. So, using (A-1),

$$
R\left(D^{*}\right) \beta-R\left(D^{* *}\right) \beta=\frac{D^{* *} R^{\prime}\left(D^{* *}\right)}{R\left(D^{* *}\right)}>0
$$

And, then, $D^{*}>D^{* *}$. 


\section{B}

\section{Panel-VAR}

Detailing more the model in equation (3-1): Specification 1: only controled by fixed effects and using Arellano-Bover estimator; Specification 2: add Growth Rate; Specification 3: add Federal Reserve (2 years, TBill); Specification 4: add Commidities Price; Specification 5: add VIX (close). The countries used are: Argentina, Brazil, Bolivia, Chile, Colombia, Costa Rica, Dominican Republic, Ecuador, El Salvador, Guatemala, Jamaica, Mexico, Nicaragua, Panama, Paraguay, Peru, Uruguay and Venezuela.

As we mentioned, we also propose a second model (Model 2) in order to verify the effect of impositions of capital controls on FDI, Debt and Porfolio Equities accounts.

The model proposed here will take the following first-order VAR:

$$
z_{i, t}^{\prime}=\Gamma_{0}^{*}+\Gamma_{1}^{*} z_{i, t-1}^{\prime}+\Psi^{*} x_{t}+f_{i}^{*}+\epsilon_{t}^{*}
$$

Where the vector $z_{i, t}^{\prime}$ represents the endogenous variables and $x_{t}$ the exogenous controls. The variable $f_{i}^{*}$ is the individual characteristic of each country. The first lag of the variables was the best fit selection criterion through the MBIC, MAIC and MQIC statistics. The results are presented in the Figure B.1 and in the Table B.2. As we already mentioned, it seems that the positive dynamic in NFA account due to the controls may be had driven by the positive dynamic in portfolio equitie accounts. 


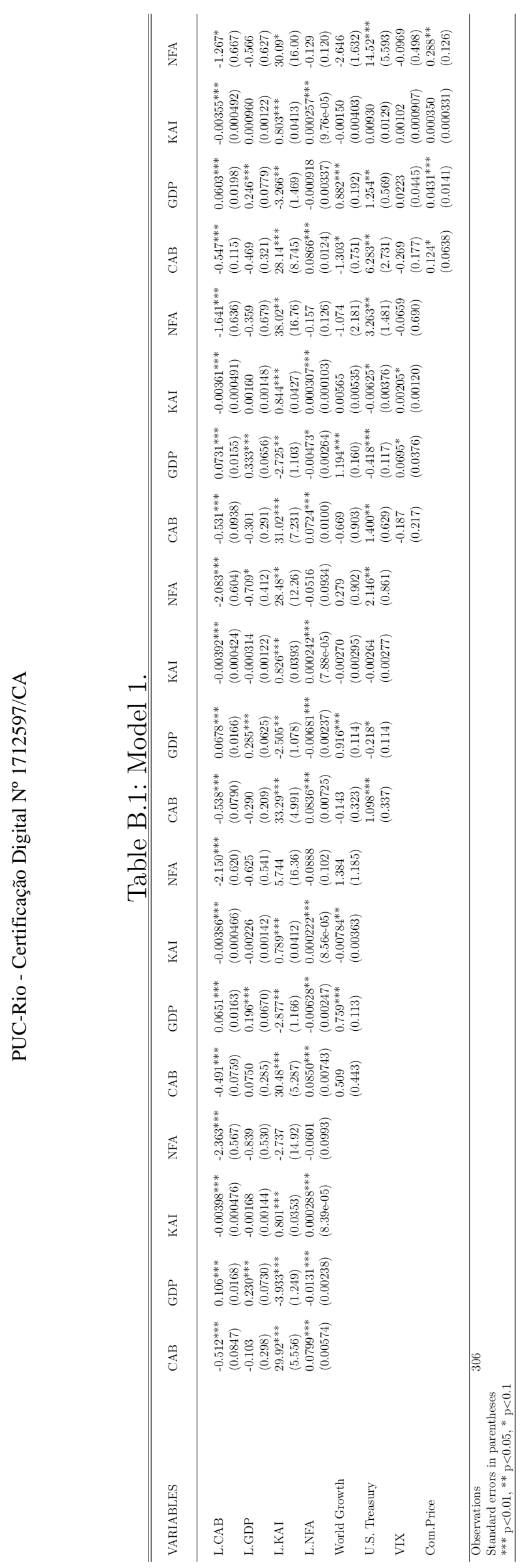


Figure B.1: Orthogonalized IRF - 95\% IC; Impulse: Response. The first quadrant is controlling only by World Growth, the second World Growth and U.S. Treasury and so on.
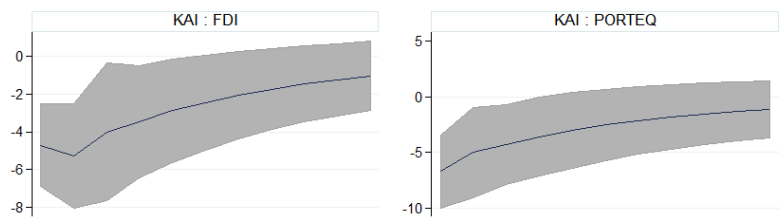

KAI : DEB

KAI : KAI
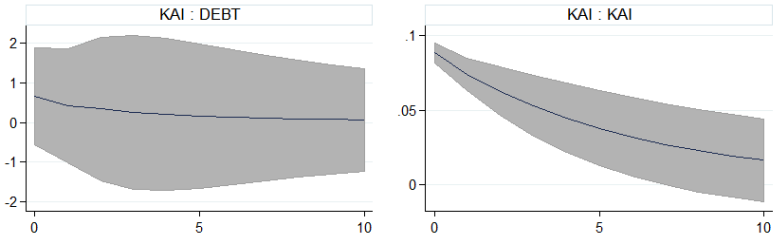

KAI FDI

KAI : PORTEQ
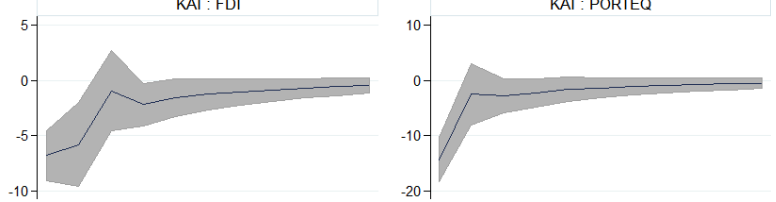

ป
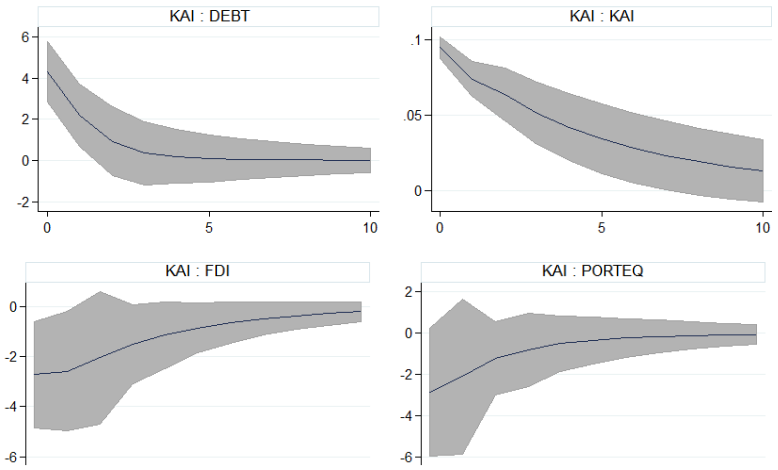

KAI : DEBT
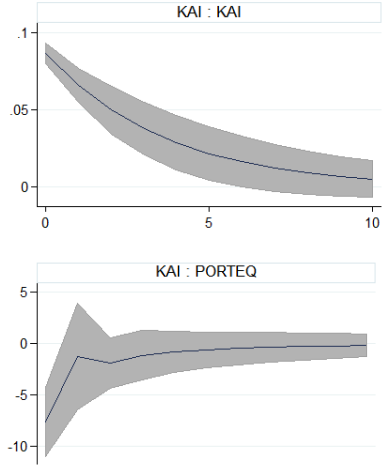

KAI : DEBT

KAI : KAI
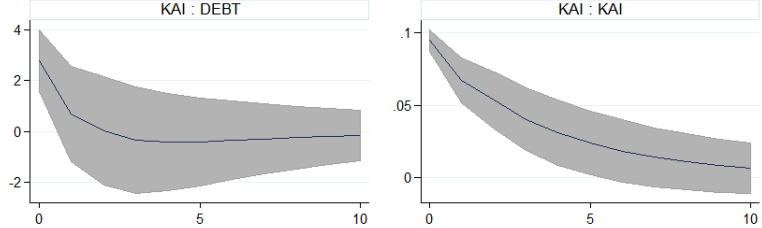


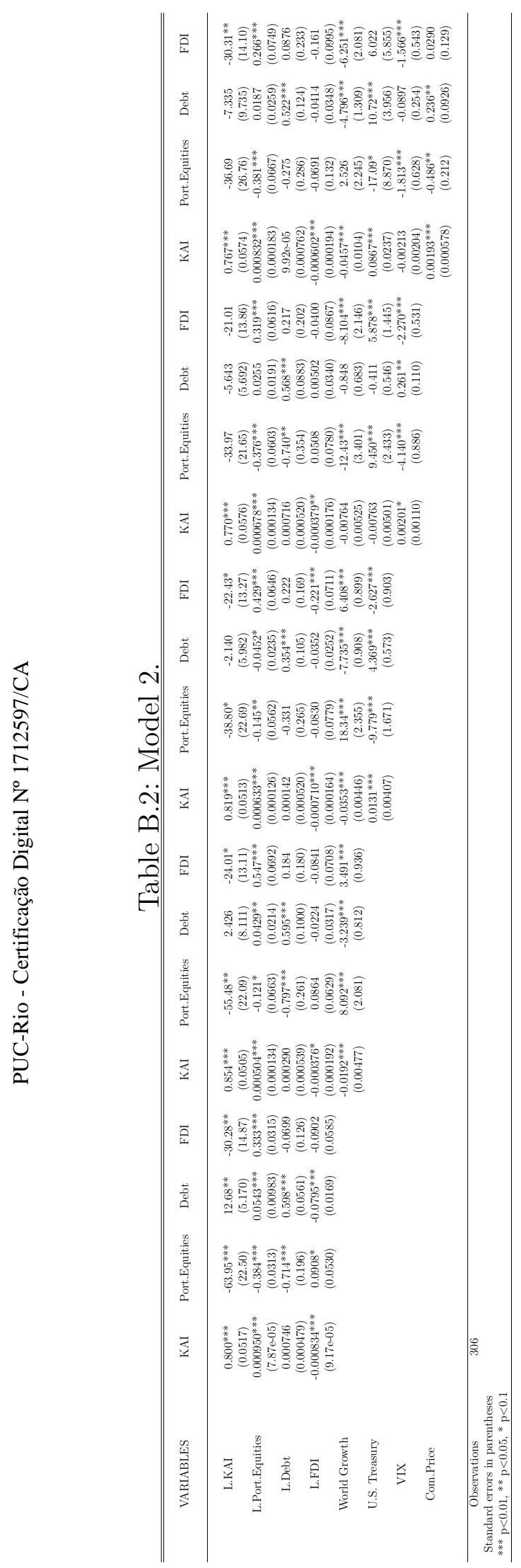




\section{C \\ Euler Equation}

In order to get precision in the cross-section, we can have information by also interpolating the annualized variables from the empirical part in monthly. This will set two kinds of models for the Brazilian variables: Model (1) and Model (2), presented in Table 2.4. The interpolation was made in two ways: a linear and a quadratic one. Here we set the relationship that comes from the quadratic interpolation, Table B.2, vis-a-vis the already presented linear interpolation, Table B.1.

Table C.1: Estimation: Linear Interpolation

\begin{tabular}{lll}
\hline \hline VARIABLES & Residuals(1) & Residuals $(2)$ \\
& & \\
\hline Current Account & $-0.00352^{* *}$ & -0.00267 \\
& $(0.00172)$ & $(0.00185)$ \\
Net External Position & -0.000202 & -0.000221 \\
& $(0.000183)$ & $(0.000187)$ \\
Constant & $-0.125^{* * *}$ & $-0.107^{* * *}$ \\
& $(0.0323)$ & $(0.0356)$ \\
& & \\
\hline Observations & 197 & 185 \\
R-squared & 0.019 & 0.013 \\
Robust standard errors in parentheses & & \\
$* * * \mathrm{p}<0.01, * * \mathrm{p}<0.05, * \mathrm{p}<0.1$ & & \\
\hline
\end{tabular}

Table C.2: Estimation: Quadratic Interpolation

\begin{tabular}{lll}
\hline \hline VARIABLES & Residuals(1) & Residuals $(2)$ \\
\hline \multirow{2}{*}{ Current Account } & $-0.00259^{*}$ & -0.00208 \\
& $(0.00134)$ & $(0.00145)$ \\
Net External Position & $-0.000269^{*}$ & $-0.000285^{*}$ \\
& $(0.000160)$ & $(0.000164)$ \\
Constant & $-0.156^{* * *}$ & $-0.141^{* * *}$ \\
& $(0.0352)$ & $(0.0389)$ \\
& & \\
\hline Observations & 208 & 196 \\
R-squared & 0.018 & 0.015 \\
Robust standard errors in parentheses & & \\
$* * * \mathrm{p}<0.01, * * \mathrm{p}<0.05, * \mathrm{p}<0.1$ & & \\
\hline
\end{tabular}

Residuals (1) come from the especification with fewer instruments; Residuals (2), with more instruments. As we can see, the negative relationship between Residuals/Capital Controls remains. ${ }^{1}$

1 The Durbin-Wu-Hausman test still is valid. 
D

\section{Bayesian Estimation}

Table D.1: Estimated parameters. first, $\zeta$; second, $\phi$

\begin{tabular}{lcccc}
\hline \hline Variable & Prior Mean & CI-90\% & Prior & Posterior Mean \\
\hline$\zeta$ & 0.1 & $0-0.08$ & Beta & 0.034 \\
$\phi$ & 0.2 & $0.15-0.31$ & Beta & 0.2 \\
\hline
\end{tabular}

Figure D.1: Multivariate Convergence Diagnostic.
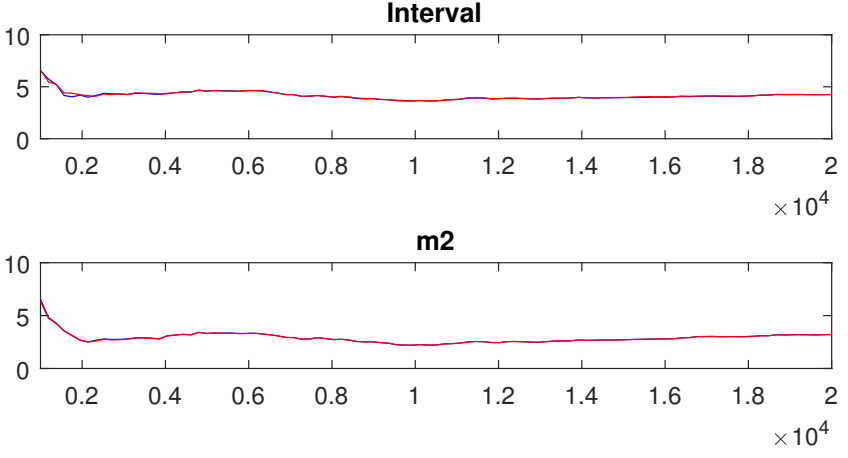

m3

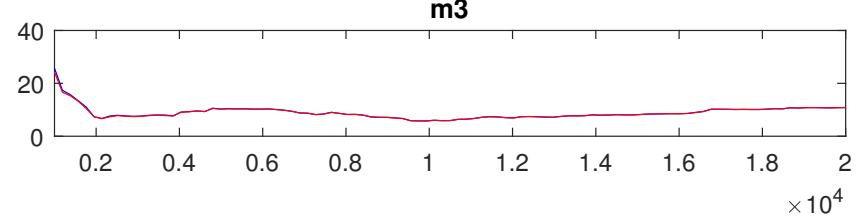

The estimation was made using Total Current Account Balance for Brazil as share of GDP - FRED. About Figure C.1, the first chart ("Interval") is an interval constructed from an $80 \%$ of confidence around the parameter mean; $\mathrm{m} 2$ and $\mathrm{m} 3$ have the same idea, but around the second and the third moments, respectively. We can see that this criteria was made.

The Figure C.1 exposes the results for Metropolis-Hastings simulations in aggregated level. Here we look for the convergence between the two lines, red and blue, which represent specific measure of the parameter vectors, built from the Monte Carlo Markov Chain. The goal is to have both lines stable after many draws, and converging, with one over the other, being relatively constant. 